\title{
URBANIZATION AND INDUSTRIALIZATION
}

\section{By Vassilios Filias}

\section{A. Population Change and Urbanization, 1960-61}

I. In all geographical departments of Greece there has been noticed a significant population change since 1920. Until 1928 the population of the country increased because of the compulsory exodus of the Greeks from Asia Minor which followed the great military defeat of 1922.

The most important population increase was noticed in the Greater Athens Area during the period 1920-28. Also in Macedonia which has shown a considerable density rate there was an increase from 30.9 to 40.5 inhabitants per square kilometer while Thrace showed a greater increase from 24.1 to 34.8 inhabitants per square kilometer.

The following table shows the distribution of the Greek population in big geographical departments in 1928.

TABLE I

\begin{tabular}{|l|c|c|}
\hline \multicolumn{1}{|c|}{ AREA } & POPULATION 1928 & $\begin{array}{c}\text { \% ON TOTAL } \\
\text { POPULATION }\end{array}$ \\
\hline Greater Athens & 802,000 & 12.92 \\
Rest of Central Greece & 790,842 & 12.74 \\
Peloponnese & $1,053,327$ & 16.97 \\
Ionian Islands & 213,157 & 3.44 \\
Macedonia & $1,412,477$ & 22.76 \\
Thessaly & 493,213 & 7.95 \\
Epirus & 312,634 & 5.05 \\
Aegian Islands & 437,436 & 7.05 \\
Crete & 386,427 & 6.24 \\
Thrace & 303,171 & 4.88 \\
TOTAL & $6,204,684$ & $100 \%$ \\
\hline
\end{tabular}

In $1928,30 \%$ of the total Greek population lived in 43 cities of 10,000 or more while in 1920 the urbanization rate was $23.0 \%$ In spite of change, 
however, Greece is still an agricultural country: $55^{1 / 2}$ of its population is agricultural. Also in 1928, among the inhabitants of the cities, $44 \%$ were not born in the city they were living in that year (the refugees from Asia Minor are not included).

The following table gives us a picture of the urban population born in cities.

TABLE II ${ }^{1}$

INHABITANTS BORN OUTSIDE THE CITY OF STAY

IN 1928 AS A PERCENTAGE OF THE TOTAL URBAN POPULATION

\begin{tabular}{|l|l|}
\hline Central Greece & 54.7 \\
Peloponnese & 41.8 \\
Thessaly & 48.9 \\
Ionian Islands & 27 \\
Epirus & 44.1 \\
Macedonia & 32.2 \\
Aegian Islands & 27.1 \\
Crete & 43.4 \\
Thrace & 23.1 \\
\hline
\end{tabular}

The following table pictures the situation in cities with more than 20,000 inhabitants in 1928 .

TABLE III

COMPOSITION OF POPULATION OF CITIES

WITH 20,000 INHABITANTS AND MORE IN 1928

\begin{tabular}{|l|r|r|r|r|r|r|c|}
\hline & Natives & REFugeEs & $\begin{array}{c}\text { IMMiG } \\
\text { RANTS }\end{array}$ & Total & $\begin{array}{c}\% \\
\text { NATIVES }\end{array}$ & $\begin{array}{c}\% \\
\text { REFUG. }\end{array}$ & $\begin{array}{c}\% \\
\text { IMMIGr. }\end{array}$ \\
\hline Athens & 131,810 & 129,380 & 198,021 & 459,211 & 28.7 & 28.2 & 43.1 \\
Pireus & 68,859 & 101,185 & 81,615 & 251,659 & 27.7 & 40.0 & 32.4 \\
Salonica & 88,050 & 117,041 & 39,590 & 244,681 & 36.1 & 47.8 & 16.1 \\
Kavalla & 10,598 & 28,927 & 11,327 & 50,852 & 20.9 & 56.9 & 22.2 \\
Patras & 32,376 & 6,967 & 25,293 & 64,636 & 50.1 & 10.8 & 39.1 \\
Volos & 14,901 & 13,773 & 19,218 & 47,892 & 31.2 & 28.7 & 40.1 \\
Xanthi & 13,257 & 14,867 & 7,788 & 35,912 & 37.0 & 41.4 & 21.6 \\
Heraklion & 15,421 & 14,069 & 9,741 & 39,231 & 39.3 & 35.9 & 24.8 \\
Corfu & 22,582 & 2,064 & 9,547 & 34,193 & 66.1 & 6.0 & 27.9 \\
\hline
\end{tabular}

${ }^{1}$ Source: Bernard Kayser, Geographie Humaine de la Grece, Paris, 1963, page 32. 
TABLE III (continued)

\begin{tabular}{|l|r|r|r|r|r|r|r|}
\hline & NATIVES & RE FUGEES & \multicolumn{1}{|c|}{$\begin{array}{l}\text { IMMIG } \\
\text { RANTS }\end{array}$} & TOTAL & $\begin{array}{c}\% \\
\text { NATIVES }\end{array}$ & $\begin{array}{c}\% \\
\text { REFUG. }\end{array}$ & $\begin{array}{c}\% \\
\text { IMMIGR. }\end{array}$ \\
\hline Komotini & 14,134 & 10,745 & 6,672 & 31,551 & 44.8 & 34.1 & 21.1 \\
Drama & 6,161 & 22,601 & 3,424 & 32,186 & 19.2 & 70.2 & 10.6 \\
Kalamata & 12,905 & 3,587 & 12,469 & 28,961 & 44.6 & 12.4 & 43.0 \\
Serres & 10,708 & 14,950 & 3,982 & 29,640 & 36.2 & 50.4 & 13.4 \\
ivytilini & 12,485 & 14,820 & 4,356 & 31,661 & 39.5 & 46.8 & 13.7 \\
Chania & 14,945 & 6,925 & 10,369 & 32,239 & 46.4 & 21.4 & 32.1 \\
Larissa & 9,427 & 4,400 & 12,034 & 25,861 & 36.5 & 17.0 & 46.5 \\
Chios & 13,651 & 9,357 & 3,159 & 26,167 & 52.3 & 35.7 & 18.0 \\
Hermoupolis & 11,978 & 3,032 & 6,406 & 21,416 & 55.9 & 14.2 & 29.9 \\
Yannina & 10,251 & 3,117 & 8,131 & 21,499 & 47.7 & 14.5 & 37.8 \\
Pyrgos & 11,414 & 772 & 8,130 & 20,496 & 55.7 & 3.8 & 40.5 \\
Trikala & 13,548 & 632 & 7,937 & 22,117 & 61.4 & 2.8 & 35.8 \\
\hline
\end{tabular}

Therefore, as we can conclude from the presentation of the above table, the average composition of the total population of cities with 20,000 inhabitants and more is as follows:

$\begin{array}{ll}\text { Natives } & 35 \% \\ \text { Refugees } & 31.7 \% \\ \text { Immigrants } & 33.3 \%\end{array}$

II. During the period 1928-40 there was an increase of the urban population exceeding the population increase of the country which is significant. The total population of Greece increased by 1.6 million while the urban by 450,000 and reached the number of 2,350,100 in 1940 from 1,900,196 in 1928. During the same period the Greater Athens Area shows a rapid increase of $40.2 \%$ while the rest of the cities undergo a much slowerpace of increase.

III. The period of 1940-1945 is one of suffering because of the war and Occupation. During this period the population suffered from significant losses amounting to 6.8 and $8.2 \%$ of the population while at the same time there was a natural decrease which amounted to 240,000 births. The result of these unfavourable conditions was a very small natural increase betwe en 1940 and 1951. It is interesting to know that in spite of the annexion of the Dodecanese, the total of narural increase just reached the rate of $2.31 \%$ ( 173,000 persons) which is $0.2 \%$ yearly.

On the contrary, the urban population increases significantly because 
of the big population movements from the agricultural areas due to the frightening climate created by the war. During the period 1940-1951 the urban population shows an increase of 458,000 persons, or $20 \%$. It is perhaps the first time that this increase does not take place only in the Capital which suffers under the foreign yoke (22.6\%) but an increase between $25-40 \%$ is also noticed in some provincial cities. Only in some cities of Northern Greece occupied by the Bulgarians we notice a population decrease (Kavalla, Komotini, Xanthi, Drama).

IV. The period between 1951-1961 is of significant importance because of the big population movements which determined the demographic changes of the after war years. The agricultural population during this period remains almost constant $(+1.4 \%)$. We notice an increase of the agricultural population only in 76 provinces while in 72 there is an absolute decrease. It is evident, however, that even in the provinces showing a population increase there is an exodus of population, a fact which is important compared to the population increase of these regions - considering as a basis the accredited natural increase of the population.

Furthermore, with regard to the small cities $(2-10,000)$ the natural increase between 1951-1961 is also small (+1.25\%) which is an indication that the small cities constitute significant attraction poles in contrast to the entirely agricultural areas. This conclusion is supported by the fact that the agricultural population increase in 42 provinces of Greece and the agricultural population decrease in 23 provinces are directly correlated and analogous to the corresponding movements of the population of these small cities which are characterized as semi-urban by the National Statistical Service of Greece. (It should also be mentioned that th: ce is a total of 113 provinces with agricultural and semi-urban population, based on the definition of the National Statistical Service of Greece).

On the contrary, in 55 cities in Greece there are significant changes having taken place during the period 1951-61. In four cities we have an increase of more than $30 \%$, in 14 cities $20-30 \%$, in 13 cities $10-20 \%$, in 17 cities less than $10 \%$. Seven cities show a clear population increase.

Basically, the most significant increase of urban population has taken place in the three big geographical departments of Greece, Central Greece, Macedonia, and Crete.

Generally speaking, the relationship between urban and nural areas is determined between 1951 and 1961 to the benefit of the former. This is supported by the fact that 31 out of 55 cities of Greece (that is 3/5) show an increase of more than 10\%. On the contrary, in only 31 out of 147 provinces we notice an increase of more than $10 \%$ (that is $1 / 5$ of the provinces of Greece). 


\section{Secondary Sector Production and Urbanization 1951-61}

The simple criterion of the rapid increase of population of an urban area is not sufficient to determine urbanization. Indeed, during the period 1951-61, we do not notice other changes than the one of population in only three cities (Argos, Aegion, Levadia). In seven other cases, we notice a more rapid increase of about $20 \%$ or more (Agrinion, Aharnai, Salamis, Arta, Naoussa, Kilkis, Nigrita). This increase is positively related to the increase of the ratio of industry to agriculture.

According to the data of the Census of 1961 there are only 12 centres which can be described as centres of secondary sector activities on the basis of the occupations of the population. Among them, Kastoria, Xanthi, and Hermoupolis are handicraft centres, Salonica, Kavalla, Patria, Kalamata, Larissa, Herakkion, Ptolemais, Chalkis, Elefsis are industrial. This picture cannot be complete without adding (a) Volos, which is both an industrial and commercial centre (b) Greater Athens Area and Chania which are centres of secondary sector activities, commerce and services at the same time and (c) Kozani also a centre of secondary sector activities and services. The definition of the above 17 urban centres as industrial has been given on the basis of the Greek standards. ${ }^{2}$

In seven out of the above mentioned industrial centres (out of which one has a mixed activity) the flowing out of the population was greater than the inflow, while at the same time (excluding Athens and Salonica) the biggest inflow took place in the urban centres very close to Athens like Elefsis (30 minutes from Athens) and Chalkis (90 minutes from Athens). Secondly, in spite of the expected results in the three previously mentioned transformation centres, the percentage of the economically active population ${ }^{3}$ represented only $30 \%$ of the total population and only in five cases (Athens and Salonica included) the economically active population exceeded the average, reaching the percentages of 37.2 and 43.4 of the total population.

II. It is meaningful for the object of our study to take into consideration the source of the Gross National Product as well as its possible clas-

${ }^{2}$ The department of regional planning of the Centre of Economic Research bas defined as industrial centres the ones having a rate of more than $40 \%$ employed in secondary sector activities, as commercial centres the ones baving more than $15.6 \%$ employed in commerce, as centres of services the ones having a rate of more than $25.6 \%$ employed in services and as centres of transport the ones having a rate of more than $9 \%$ employed in secondary sector activities, and agricultural centres the ones having a rate of more than $30 \%$ engaged in agriculture.

${ }^{3}$ According to the definition of the National Statistical Service of Greece, economically active are characterized tho se who were employed during the week before the Census was taken. 
TABLE V

PER CAPITA GROSS

REGIONAL INCOME

REGIONAL INDEXES

\begin{tabular}{|l|r|c|c|c|}
\hline \multicolumn{1}{|c|}{ AREA } & DRACHS. & U.S.A. & GREECE = 100 & $\begin{array}{l}\text { NOMOS OF } \\
\text { ATTICA = 100 }\end{array}$ \\
\hline Nomos of Attica & 18,801 & 626.70 & 156.30 & 100.00 \\
Rest of Greece & 9,215 & 307.70 & 76.60 & 49.00 \\
Peloponnese & 10,658 & 355.20 & 80.60 & 56.70 \\
Thessaly & 8,193 & 297.10 & 74.10 & 47.40 \\
Epirus & 6,846 & 228.20 & 56.90 & 36.40 \\
Macedonia & 11,137 & 371.20 & 92.60 & 59.20 \\
Thrace & 8,605 & 286.80 & 71.50 & 45.70 \\
Crete & 7,938 & 264.60 & 66.00 & 42.20 \\
Aegian Islands & 8,229 & 274.30 & 68.40 & 43.70 \\
Ionian Islands & 6,944 & 231.40 & 57.70 & 36.90 \\
\hline Greece & 12,028 & 400.90 & 100.00 & 64.00 \\
\hline
\end{tabular}

Generally speaking, the per capita income in the Nomos of Attica (which is almost the same as the Greater Athens Area) is $2 \frac{1}{2}$ timeshigher than the average per capita income of the country. Moreover, the purchasing power of the inhabitants of the capital covers $53 \%$ of the purchasing power of the country as a whole.

It is interesting to present here the results of a research project on Households attempted by the National Statistical Service of Greece. The difference of income among the most significant greek cities according to population size is presented in the following table:

\section{TABLE VI}

INCOME OF HOUSEHOLD HEAD ACCORDING TO SIZE OF WEEKLY INCOME AND ACCORDING TO POPULATION SIZE OF CITIES 1957/1958*

\begin{tabular}{|l|r|r|r|r|r|c|}
\hline & $\begin{array}{c}\text { GREATER } \\
\text { ATHENS } \\
\text { AREA }\end{array}$ & SALONICA & $\begin{array}{c}\text { CITIES } \\
\text { wITH } \\
\text { WIT-80,000 }\end{array}$ & $\begin{array}{c}\text { CITIES } \\
\text { wITH } \\
\text {-10,000 }\end{array}$ & $\begin{array}{c}\text { ALL } \\
\text { HOUSE- } \\
\text { HOLDS }\end{array}$ & $\begin{array}{c}\text { SIZE } \\
\text { OF } \\
\text { SAMPLE }\end{array}$ \\
\hline UP to 249 & 22.30 & 38.60 & 28.00 & 36.95 & 28.85 & 3.48 \\
$250-449$ & 23.40 & 26.50 & 29.25 & 29.70 & 26.30 & 6.15 \\
$450-799$ & 28.10 & 24.15 & 25.50 & 20.35 & 25.30 & 7.97 \\
$800-1099$ & 8.40 & 4.35 & 6.50 & 5.40 & 6.85 & 3.72 \\
$1100-1599$ & 4.90 & 2.00 & 2.00 & 3.60 & 3.60 & 2.31 \\
$1600+$ & 5.50 & 1.70 & 3.75 & 2.10 & 3.90 & 2.05 \\
Refused to declare & 7.40 & 2.70 & 5.00 & 1.90 & 1.90 & - \\
All households & 100.00 & 100.00 & 100.00 & 100.00 & 100.00 & - \\
Size of sample & 12.07 & 2.98 & 4.00 & 6.63 & 25.68 & - \\
\hline
\end{tabular}


The importance of daily wages to secondary sector activities varies according to the weight of the secondary sector production for the income formation in each city, However, there appear to be significant differences in wages mainly between Athens and the rest of the cities. This is not true among the rest of the cities. It has been found out that the daily wages in Athen s exceeded by $20 \%$ the lowest average wages in provincial cities in seven industrial branches. In 18 industrial branches however, the wages in Athens exceeded by only $10 \%$ the wages in the provincial cicies. ${ }^{5}$

III. In Greece, the evolution of social and industrial patterns which had started to be noticed before the war, led to the establishment of a large scale disequilibrium in the greek sphere after the war. Already in 1961, $1 / 3$ of the population of the country had settled in $5 \%$ of the total greek territory, $1 / 2$ in $15 \%$. At this point we should ask ourselves: Did this evolution result from a healthy urbanization process?

The following table pictures the population distribution in large geoTABLE VII

SURFACE AND POPULATION OF GREECE ACCORDING TO GEOGRAPHICAL DEPARTMENTS, ETC.

\begin{tabular}{|c|c|c|c|c|c|c|}
\hline $\begin{array}{l}\text { GEOGRAPHICAL } \\
\text { DEPARTMENT }\end{array}$ & $\begin{array}{l}\text { SURFACE IN } \\
\text { THOUSANDS } \\
\text { SQUARE } \\
\text { KILOMEIERS }\end{array}$ & $\begin{array}{l}\text { NUMBER OF } \\
\text { INHABIT, IN } \\
\text { TOWNS } \\
1961\end{array}$ & $\begin{array}{l}\% \text { ON THE } \\
\text { TOTAL OF } \\
\text { POPUL. OF } \\
\text { GREECE } \\
100.0\end{array}$ & $\begin{array}{l}\text { CITIES } \\
\text { WITH MORE } \\
30,000\end{array}$ & $\begin{array}{l}\text { NUMBER } \\
\text { OF INHAB. }\end{array}$ & $\begin{array}{l}\% \text { ON THE } \\
\text { TOTAL OF } \\
\text { URBAN POP. }\end{array}$ \\
\hline Total of Greece & 130.9 & 8,389 & 100.0 & $\ldots \ldots$ & - & - \\
\hline $\begin{array}{l}\text { Greater Athens } \\
\text { Area }\end{array}$ & 0.4 & 1,853 & 22.1 & $\begin{array}{l}\text { Athens }+ \\
\text { Pireus }\end{array}$ & - & - \\
\hline $\begin{array}{c}\text { Central Greece } \\
\text { \& Eubea }\end{array}$ & 24.2 & 971 & 11.6 & $\cdots \cdots$ & - & - \\
\hline Peloponese & 21.1 & 1,096 & 13.1 & Patras & 95 & 2.6 \\
\hline Ionian Islands & 2.3 & 213 & 2.5 & Kalamata & 38 & 1.0 \\
\hline Thessaly & 14.0 & 695 & 8.3 & $\begin{array}{l}\text { Volos }+ \\
\text { Larissa }\end{array}$ & $\begin{array}{l}67 \\
55\end{array}$ & $\begin{array}{l}1.8 \\
1.5\end{array}$ \\
\hline Macedonia & 34.0 & 1,891 & 22.5 & $\begin{array}{l}\text { Salonica } \\
\text { Kavalla } \\
\text { Serres }\end{array}$ & $\begin{array}{r}374 \\
45 \\
0 \\
27\end{array}$ & $\begin{array}{r}10.3 \\
1.2 \\
1.1\end{array}$ \\
\hline Epirus & 9.1 & 353 & 4.2 & $\begin{array}{l}\text { Drama } \\
\text { Yannina }\end{array}$ & $\begin{array}{r}32 \\
-\end{array}$ & $\begin{array}{r}0.9 \\
-\end{array}$ \\
\hline Crete & 8.3 & 483 & 5.8 & $\begin{array}{l}\text { Heraklion } \\
\text { Chania }\end{array}$ & $\begin{array}{l}63 \\
38\end{array}$ & $\begin{array}{l}1.7 \\
1.0\end{array}$ \\
\hline Aegian Islands & 9.1 & 477 & 5.7 & $\ldots$ & - & - \\
\hline Thrace & 8.5 & 357 & 4.2 & 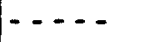 & - & - \\
\hline
\end{tabular}

Source: Statistical Yearbook of Greece, 1961

${ }^{4}$ Source - National Statistical Service of Greece. Household Survey (Athens 1961) pp. 58-59 foll. p. 321 fol.

${ }^{5}$ See. Benjamin Ward, Regional Development of Greece. K.E.P.E., Athens, 1963. page 52 foll. 
graphical departments and in the most important cities with 30,000 inhabitants or more, according to the data of the Census of 1961.

We can conclude immediately from the above table that in Central Greece and Eubea 1/3 of the population of Greece is concentrated in $13 \%$ of the total surface of the country. Another significant conclusion is that since there is only one city in Greece besides Athens with more than 100,000 , Greece lacks cities of medium size. Furthermore, it is of great importance to the object of our study that $68.6 \%$ of the urbanization is directed towards Athens which has resulted in the tremendous population increase of the Athens Metropolitan Area between the years 1951-1961 $(472,913$ persons), which is $34.4 \%$ in contrast to a $9.9 \%$ population increase of the country as a whole. $71.6 \%$ (395,630 persons) of this increase were internal migrants most of whom, according to the results of a research project, came from rural areas.

The result of these developments is the concentration of the following services in the nomos of Attica (which represents the $25 \%$ of the total population of Greece):

\title{
TABLE VIII
}

\author{
$56.8 \%$ secondary sector production (added value) \\ $73.9 \%$ utilities \\ $42.1 \%$ construction works \\ $47.2 \%$ transportation-communications \\ $58.2 \%$ commerce \\ $77.3 \%$ trust-insurance \\ $46.2 \%$ housing \\ $51.0 \%$ public administration \\ $52.9 \%$ health \\ $29.8 \%$ education \\ $51.0 \%$ rest of services
}

Furthermore, $57.8 \%$ of the public revenues, $43.2 \%$ of the public receipts, and $50-70 \%$ of the total of the investments in industry, tourism and buildings were concentrated in the Greater Athens Area.

More specifically, in regard to industry, $28 \%$ of the buildings of the secondary sector occupations were concentrated in the Greater Athens Area in 1963. This distinction permits us to establish a criterion of classification between handicraft industry and industry. Industrial stores which occupied more than 10 persons represented a $50.4 \%$ in the Greater Athens Area ( $54.8 \%$ of the total occupied in this professional category). It should be noticed, however, that between 1958 and 1963,65\% of the 
increase of industrial stores and $85 \%$ of the increase of industrial occupations took place in the Greater Athens Area.

This disproportionate increase of Athens participation in industrial activity between 1958 and 1963 resulted in a significant average yearly rate of income increase of about $9 \%$ in the nomos of Attica, in contrast to an average yearly rate of $6.45 \%$ for the rest of the country.

Salonica, the second big city in the country showed a percentage of $11.8 \%$ of the urban concentration tendencies between the years 1951 and 1961 in such a way that this city covers more than $16.8 \%$ of the total of the population of Macedonia and Thrace.

Today, we find $75 \%$ of the most important industrial activities (secondarily sector units of industry) concentrated in the two big cities in Greece and 50\% are occupied in secondary Sector activities.

B. As we have already mentioned according to the data of the Census of 1961 there were 55 urban centres in Greece which had 3,628,105 inhabitants thus covering the $43.3 \%$ of the total population of Greece $(8,388,533)$. During tha decade between $1951-61$, the urban population increased by 690,366 persons or $23.5 \%$.

During the same period the populations in the secondary sector activities increased by 34,000 persons (from 450,000 to 484,400 ) or $7.6 \%$ in contrast to a $15 \%$ increase of the total labor power of the country. In addition to this, between 1958 and 1963 the per cent of increase of those employed in secondary sector production is just $3.3 \%$ covering only $13.5 \%$ of the yearly natural increase of the population. As a result of this, in 1964 only $12.5 \%$ of the total labor power were occupied in secondary sector activities. It should be taken into consideration that the above numbers refer to the total of the secondary sector production which covers $92.5 \%$ of the total number of stores which occupy $79.4 \%$ of the total of those employed in secondary sector activities and give $39 \%$ of the income of the secondary sector activities by small handicraft stores which occupy less than ten persons each.

The average rate of yearly increase of the greek industry is:

$$
\begin{array}{rr}
1951-1955 & 10 \% \\
1956-1960 & 0 \% \\
1961-1965 & 7.1 \%
\end{array}
$$

Although the numbers seem to be satisfactory for an industrially underdeveloped country like Greece, they are insufficient. This argument could be based on the fact that the investments in industry represented $11.5 \%$ of the national income of the country in 1958, and only $10.9 \%$ in 1964 .

From the above presentation, it is evident that immigration towards the cities could not be absorbed in industry but in the rest of the branches of 
economic activity. On the basis of data provided by the National Statistical Service of Greece, the distribution of male population according to branches of economic activities in the total of greek cities is as follows:

TABLE IX

\begin{tabular}{|l|c|c|}
\hline & NON-IMMIGRANTS & IMMIGRANTS \\
\hline Secondary sector activity & 29.1 & 27.0 \\
Constructions & 11.3 & 18.3 \\
Commerce & 20.2 & 12.8 \\
Transportation & 12.5 & 9.1 \\
Rest of Service & 19.7 & 25.8 \\
Not classified & 7.2 & 7.0 \\
Services & 100.0 & 100.0 \\
\hline
\end{tabular}

More specifically on the basis of data provided by the National Statistical Service of Greece, the population of Athens was occupied in the following branches of economic activity in 1959.

TABLE X

\begin{tabular}{|l|r|r|r|c|}
\hline & TOTAL & \multicolumn{1}{|c|}{$\%$} & MALE \% & FEMALE \% \\
\hline Agriculture & 9,600 & 1.5 & 1.8 & 0.6 \\
Mines & 3,000 & 0.5 & 0.6 & 0.1 \\
Secondary Sector & & & & \\
Activities & 192,200 & 29.8 & 28.7 & 33.3 \\
Energy & 10,200 & 1.6 & 2.0 & 0.3 \\
Construction Works & 52,900 & 8.2 & 10.8 & 0.1 \\
Commerce & 112,400 & 17.4 & 19.0 & 12.9 \\
Transport & 61,600 & 9.5 & 12.0 & 2.1 \\
Rest of Services & 192,100 & 29.8 & 23.8 & 48.0 \\
Not classified & 10,700 & 1.7 & 1.3 & 2.6 \\
& & & & 100.0 \\
\cline { 2 - 5 } Total & 644,700 & 100.0 & 100.0 & \\
\hline
\end{tabular}

In Salonica, the distribution of the economically active population of both sexes is as follows, according to the data of the National Statistical Service of Greece in 1961. 
TABLE XI

\begin{tabular}{|l|r|r|}
\hline & NUMBER OF EMPLOYED & $\%$ \\
\hline Agriculture & 3,700 & 3.0 \\
Mines & 300 & 0.2 \\
Secondary Sector & 38,400 & 31.3 \\
Activities & 1,800 & 1.5 \\
Energy & 11,900 & 9.7 \\
Construction Works & 23,800 & 19.4 \\
Commerce & 13,100 & 10.7 \\
Transport & 28,500 & 23.2 \\
Rest of Services & 1,300 & 1.0 \\
Not classified & & \\
\hline
\end{tabular}

The distribution of the economically active population in the rest of the cities for both sexes is as follows: (excluding Athens and Salonica).

TABLE XII

\begin{tabular}{|l|r|r|}
\hline & NUMBER OF EMPLOYED & $\%$ \\
\hline Agriculture & 99,400 & 22.1 \\
Mines & 2,100 & 0.5 \\
Secondary Sector & 103,400 & 23.0 \\
Activities & 5,600 & 1.3 \\
Energy & 33,700 & 7.5 \\
Construction Works & 62,500 & 13.9 \\
Commerce & 37,400 & 8.3 \\
Transport & 100,700 & 22.5 \\
Rest of Services & 4,100 & 0.9 \\
Not classified & & \\
\hline
\end{tabular}

We may conclude from comparing the data of the previous tables that, besides Athens and Salonica, the degree of urbanization in the rest of the cities with 10,000 and more, is rather low. To this, we should add that cases vary considerably among themselves. In these cities, it is of great importance to note that $22.1 \%$ of the economically active population are engaged in agriculture and just $23 \%$ in secondary sector activity. In the light of this differentiation, the distinction from the economically devel- 
oped countries like France, Germany and Great Britain - could be based on the fact that human settlements of about 2,000 are adequately urbanized. Therefore, the fact that $59 \%$ of the greek population live in settlements with more than 2,000 inhabitants is not of decisive importance when we estimate the degree of urbanization in the Greek society.

On the contrary, in the neighbouring Balkan countries, like Bulgaria and Yugoslavia, with much higher indexes of industrial development and employment in secondary sector activities, the urban population represents $29.2 \%$ (1956) and $24.3 \%$ (1965) respectively, while the cities of more than 100,000 inhabitants do not cover more than $41.6 \%$ ( 3 cities on total of 53 cities) of the urban population in Bulgaria and $36.76 \%$ ( 7 cities on total of 119 cities) of the urban population in Yugoslavia.

\section{Development and Future Projection}

With regard to the possibilities for development, it is necessary for us to make a clear distinction between the two big cities of Athens and Salonica and the rest of the cities. It has been found out that in 30 out of these cities a population decrease took place due to inland migration, while in 23 cities the population increased due to the inflow of immigrants from other cities.

These movements took place as follows in the major geographical departments of Greece.

TABLE XIII

\begin{tabular}{|l|c|c|}
\hline & WON POPULATION & LOST POPULATION \\
\hline Central Greece & 9 cities & 2 cities \\
Peloponese & 2 cities & 7 cities \\
Epirus & 1 city & 2 cities \\
Thessaly & 3 cities & 2 cities \\
Macedonia & 8 cities & 6 cities \\
Thrace & 0 cities & 4 cities \\
Aegian Islands & 1 city & 4 cities \\
Ionian Islands & 0 cities & 1 city \\
Crete & 1 city & 2 cities \\
& 25 cities & 30 cities \\
\cline { 2 - 3 } &
\end{tabular}

On the basis of Prof. Kayser's analysis, we can describe 17 cities as 'declining' cities, 22 as 'static' and 15 cities only as 'dynamically developing'. 
From the data available from the Census of 1961 , we may conclude that the population of the provincial cities increased by 143,400 persons or $10.3 \%$ of their population because of intemal migration during the fiveyear period 1956-61, the same cities showed a decrease of their old population of about 129,300 persons or $9.3 \%$ of their population.

The fact that old 'urbanized' people moved to the two major cities and were substituted by people of agricultural origin created a new social environment lacking in leadership of almost all social groups, capital, etc. It is important, that the newcomers to the provincial cities are absorbed in trade, transport, and services, (47\%). To this, we should add those who were classified as 'did not declare' (7\%).

The most noteworthy fact, however, is that 13 out of the 16 'dynamically developing' cities owe their development to the flourishing of agriculture within their areas. Of the rest Kastoria developed because of the fur industry, while Kozanzi and Ptolemis owe their development to the lignite mines.

It should be not forgotten that in regard to the employment of the immigrants from rural areas, the above conclusions are true mutatis-mutandis. The same can hold true for those newcomers to the Athens Metropolitan Area who were absorbed in the secondary sector activities (30.9\%).

Therefore, it was very correctly argued by Mr. N. Catocianos in his paper presented to the Conference for Municipal Research in Toronto ${ }^{6}$ that the development of secondary sector production will take the form of increase of productivity, automation and inten sity of invested capital rather than the form of increased employment opportunities.

\section{Urbanization and Industrial Capital Formation}

The phenomenon of mass movements of agricultural populations towards the urban centres characterizes development in the 'under developed' countries after the war. It constitutes a very important factor of restraint on capital formation which has not been studied adequately by the theorists of economic underdevelopment.

The above mentioned movements are related to the trend towards urbanization which characterized the economies of the Vest during the period of the rise of capitalism. This relationship, however, is superficial, because the population movements towards the urban centres followed the development of industry and the multiplication of the industrial production. On the contrary, in the 'underdeveloped' countries today, these movements are followed by the increase of employment in tertiary

\footnotetext{
${ }^{6}$ Athens Study Group - D. and N. Catochianos, A. Markopoulou, Comments on:
} Planning and Urban Design, p. 17 
sector activities (services of all categories) or take place independently of the real needs of the Economy thus speeding up the forms of socioeconomic marginality in the cities.

Furthermore, the liberation of labour hands from agriculture resulted in a revolutionary method of cultivation, and use of fertilizers during the period of the rise of Capitalism in the West. Very correctly Regnar Nurske points out the importance of utilizing V. Liebig's invention referring to the evaluation of the possibilities of the chemical industry for cultivation purposes.

In the 'underdeveloped' economies the sequence of development of secondary sector production - i.e. rapid increase of productivity in agriculture - liberation of working hands from agriculture - population towards the cities - is lacking. On the contrary, we notice a very fast urbanization process although the economy remains basically agrarian. It has very often been argued that even a slow improvement of cultivation conditions and level of technology results in the liberation of working power who are underemployed and therefore leave for the cities. This argument is definitely correct; however, it does not answer the following question: up to which point, increase of productivity in agriculture meets the increase in demand of agricultural products which follows the rapid urbanization. Also, up to which point the degree of commercializing the agricultural products meets the needs of the urban population. Even though we may not accept the idea that the real income increases in the cities, the plain fact of population movement to the cities brings with it an increase in the demand of commercialised agricultural products which in the past were covered by the consumption of primary goods produced by the agricultural family. Now, these needs should be met in the market and should be provided by the agricultural sector of the economy. Besides the arguments presented above, the phenomenon of the urbanization is accompanied by changes in patterns of diet which brings about the need for qualitative-re-adjustment of the agricultural production.

If we do not take into consideration the above not so realistic hy: pothesis, that is that the real average income of those who move to the cities does not increase, the problem is more important. Employment in tertiary sector activities in the urban centres, creates incomes which increase the average real income of those who moved to the cities. This increase of the real income of the newcomers to the cities, exercises pressure on the prices of the products, a pressure which becomes stronger when the per capita increase of the real income of the urban population is higher than the per capita increase of the agricultural product. It has been found out that in the underdeveloped economies the pace of increase of the per capita real income is much faster than the pace of increase of the per capita agricultural products. 
For example, Greece has a higher rate of gross national product coming from the tertiary sector (44\%) than Western Germany (42\%). Under these circumstances, regardless of any development in the secondary sector, we notice a pressure on the level of prices which results from urban demands. Greece is a typical example. Thus, between 1960-1962 the level of prices of agricultural and cattle breading products showed the following developments:

\section{INCREASE}

$\begin{array}{ll}1960 & 6.3 \% \\ 1961 & 2.6 \% \\ 1962 & 5.4 \% \\ 1963 & 2.8 \% \\ 1964 & 2.4 \% \\ 1965 & 7.8 \%\end{array}$

The impact on the levels of prices of agricultural products influences the process of capital formation in two ways. On the one hand, the increase of prices of goods keep the spiral shape of salaries - prices in Economy. On the other hand, the monetary authorities are pressed towards taking limiting and stable measures. The first development prevents investment activity because the cost of employment increases; the second development constitutes a factor of restraint on investing mainly because

(a) it increases the cost of capital

and (b) it brings about an artificial price control and naturally it limits the profit margins of the industrial business.

G. Maynard ${ }^{7}$ very correctly points out the possibility of interference of relative phenomena pertaining to an underdeveloped economy even if there is a significant population movement towards the cities because of the criterion of new industrial units in a scale which necessitates the breaking of a part of the labour power from the agricultural sphere of the Economy.

Again, however, the increase of the real income of this particular part of labour power as well as the increase in demand of agricultural products creates the problem of increase of productivity in a very different scale than the previous one.

As very correctly Maynard points out, the increase of the industrial production does not answer the problem which is created by the increased demand for agricultural products. This means that there is an increase of demand for food products much higher than the increase of the industrial

${ }^{7}$ G. Maynard: The Economic Development and the Price Level, London 1963, p. 50 foll. 
products. Again, he mentions that the problem is independent of the success or not of the economic policy to reach the desired point of savings, but it is a result of the unbalanced development of the two basic productive branches of the Economy. The use of tax policy for the deduction of excess income from the major consumption groups and the limiting of demand in the levels of 'commissionary' ability of the agricultural production will limit the purchasing power from the market of the industrial products thus causing a blow on the motives for investing. Besides, the composition of control in the determination of prices of the agricultural products will cause an undesired gap in the economy very dangerous for the creation of black marketing. It is, therefore, evident that it is impossible to avoid pressures of inflationary nature even if the investing activities are healthy. The problem is, therefore, the following: in what way, the inflationary pressures will be controlled by combining the necessary measures of economic policy so that an open inflation of the Economy will be a voided. In any longerm case, the problem cannot be faced without speedy modemization and rise of the level of technology which means rise of productivity of agriculture.

Within this framework we have to take into consideration the impact of the inflationary phenomena on the exports of the economy as well as the weight of the impact of an increased production of agricultural products, which is met by the imports, on the balance of payments in relationship to the process of capital making.

It is natural to have inflationary tendencies influencing the prices of exported agricultural products which are of great significance for the balance of Commerce in an underdeveloped economy.

More specifically, in regard to agricultural exports, the pressure for higher prices on the agricultural products of internal mass consumption will extend over all agricultural products which are important for an underdeveloped economy. If cost increase in agriculture does not take place, the producers of the exported agricultural products will ask for higher insurance prices. If this increase coincides with a favourable development of terms of trade of a specific economy, the consequences will be dually disastrous: (a) because they encourage inflationary tendencies

(b) because they limit the monetary margins of the Economy for the capital formation in industry.

Pressures from agricultural interest should not be underestimated in underdeveloped countries where $45.50 \%$ of the population is agricultural. It is probable that inflationary tendencies could be strengthened by agricultural interest, directly or indirectly organized rather than by pressures derived from syndicalistic interests in the cities. 
Cities in underdeveloped countries are not centres of production; they are centres of consumption, and modern huge 'bargain' areas with a high proportion of 'marginal' men (Park: Marginal Men) who live on the poor overs of the huge consumption processes. The Park hypothesis, that these elements indicate a higher mobility and better adjustment to new conditions of life, provided that they are internal migrants and that they create a new type of man, is false for the underdeveloped countries. It would be more correct to accept that the climate of social disorganisation which is found in the underdeveloped countries develops tendencies of anomie and parasitism. Besides, the total integration of these people in the cities, is slowed down because of another fact: the fact that, formany families in the urban centres the income sources are both urban and rural.

In addition, industry in underdeveloped countries is rather peculiar. Its first characteristic is that the basic branches are so well protected that foreign competition cannot 'jump over' the duties dam to compell industry modernize methods. At this point, the objective need to protect the national production and the profit ideology about monopolizing the internal market come together. Its second characteristic is the utilization of cheap labor which constitutes an economic advantage for private enterprise. At the same time, however, from the point of view of techno-economic development, in the long run it funstions restrainingly thus resulting into low productivity and lack of foreign competition. At his point also, the possibility of employment of cheap labor power contradicts the application of more rationalistic methods of production.

The third characteristic in the so-called 'Aversion of Capital' (Boeke) which is given a techno-economic definition here. Also, the increased dangers in enterprise and the long term commitment in contrast to the striking antithesis with the possibility of a relatively easier and higher profit for middle men (compradores) are considered here.

Another characteristic is a total or partial lack of industrial climate in the form of 'extemal economies' and the fifth characteristic is the multipersonal and expensive accounting of the administrative mechanism against the technical organization and production.

This indicative enumeration was attempted in order to make clear the fact that coalition of techno-economic and social terms is an unseparable matter in the secondary sector production in the underdeveloped countries. The distinction between a developing sector of the economy and an entirely static one is not and could not be absolute. In any case, the influence of the underdeveloped sector on the Economy as a whole is more effective than the 'spread effect' from the already industrialised one. This 
is because the society remains under the 'rule' of value judgement, connected with traditional patterns of social life, which lead to anti-development ideologies.

Myint, Higgings, etc. presented the techno-economic factors which limit the extension of industrial development in the 'dual societies', Boeke, however, conceived the problem of social and ideological tendencies which compose the anti-industrial and anti-development power of the opposition of the socio-political structures in the underdeveloped countries (although, the addition of 'racial differentiations' is absolutely wrong).

In regard to the primary sector production, the introduction of rationalistic methods follows a very slow pace and undergoes many restraints varying from the sticking to the extensive cultivation to the alotment of the agricultural land.

Even the mechanization of agriculture in underdeveloped countries is followed by reactions of irrational nature. For example, the tractor distribution is entirely random and the result of this is, of course, to have too many tractors in one area while elsewhere the need for tractors is not met. There exists a tendency to buy tractors of bigger horsepower than it is needed for the kind of soil and the quantity of cultivated land for reasons of personal prestige. As a consequence, the tractor is not used appropriately and the farmers borrow more than they should.

The consuming 'patterns' in underdeveloped countries could not be ccmpared to the ones in the highly undustrialized countries. For example, in Greece in an average yearly increase of national income of 6 per cent the corresponding increase of consumption is 5 per cent. ${ }^{8}$

The phenomenon, which was described by T. Veblen' as 'conspicuous consumption' and Riesman saw it as the most basic structure of the modem capitalistic societies which he described as "consuming societies', is defined in the bibliography of economic development as the 'demonstration effect'. The meaning of this is that upper class people in underdeveloped countries imitate pattems of living and consumption of the highly industrialized countries of the West.

The result of this, is a great waste of capital, which could have been used for purposes of capital accumulation, for luxury purposes. In this new environment, therefore, there are patterns of life and consumption created which prove Galbraith's conclusions that the marginal usage for the determination of a hierarchical scale of goods on the basis of needs is abolished, and that an irrational criterion to meet the dhow off need

- F.A.O. Mediterranean Development Project, Greek report, p. IV 3.

${ }^{9}$ T. Veblen, The Theory of the Leisure Class. 
dominates thus creating the abolishment of the ability for a rational hierarchy in the society as a whole. The above explanation can be supported by the view of many social scientists that 'homo economicus' is not any more the most important force but the 'homo sociologicus', whose criteria refer to prestige relations with the rest of the members of the social group.

The impact of such phenomena on the social life of the people in an affluent society is different from that in an underdeveloped one. In the 'affluent' societies which have reached the zenith of industrial development, these phenomena serve the basic needs and survival of the system up to a certain point. In underdeveloped societies, however, these phenomena appear before any industrialization and capital formation takes place, so that they hinder the development of productive powers. The need to 'show off' as a motive of human behaviour cannot be explained by economic theory which presupposes ability to generalize about the regulations of human behaviour ${ }^{10}$ based on rational activity.

However, according to our previous remarks in underdeveloped countries, the process of urbanization does not coincide with the necessary structural changes needed to accelerate industrialization.

${ }^{10}$ Wilbert Yoore: Economy and Society (N. York), p. 4. 